\title{
Analyzing Cohesion Device of Monologue Texts in Students' Text Book for Eight Grade in Academic Year 2017/2018
}

\author{
Muhamad Zayyinul Muttaqin \\ SMP CitiSchool \\ ziiaiant891@gmail.com
}

\begin{abstract}
This study aimed to describe the types of cohesive devices that were mostly used and also to find out which one the most cohesive text among texts in Students' texts book (When English Rings a Bell) for Junior High School at eighth grade in the academic year of 2017/2018. The object of this study was monologue texts that are found in students' texts book for Junior High School at eight grade in the academic year of $2017 / 2018$. This study used qualitative approach. The researcher analyzed the data; First, the data were analyzed by dividing and numbering sentences into clauses, second, putting the number of cohesive devices into tables based on types, third, putting the number of cohesive devices in the form of a percentage, the last, interpreting based on the result.
\end{abstract}

ARTICLE HISTORY

Received 24 April 2017

Accepted 13 September 2017

\section{KEYWORDS}

Text and Context; Cohesive Devices; Monologue Texts; and Students' Texts Book

\section{Introduction}

In many cases, many written texts; a reading passage, essay, or academic writing, are difficult to understand by public readers whereas they need information or news through those writings. As citied from Fadlilah's thesis (2010:1), it is stated that text is commonly difficult to comprehend. This happens not only for the students but also their lecturers, including them as an English lecturer. Although the lecturer has already translated the reading passages, the students still cannot understand well, and it is very time-consuming. That is a serious problem which makes some students are confused about what the messages are or its contents.

Therefore, public readers need a text unity, that is the cohesiveness text, and it is the tightness of the text. According to Siahaan and Shinoda (2008:3), a cohesive text is the one strategy which has some relevant clauses or components to each other. All the clauses or components of text are relevant to each other. The effect is there is no tightness in the text due to the irrelevant of clauses to each other.

This study focuses explicitly on cohesion device. It refers to the choice of words which are more influential in relating one element to other elements in a text. According to Halliday and Hasan (1976: 274), cohesion refers to the relation of meaning that exists within the text. It is a semantic relation among elements of the 
texts that make a text means. Meanwhile, Lexical cohesion itself means the cohesive effect achieved by selection of vocabulary. These two kinds of cohesion deal with the unity within the texts, so students or teachers are easy to state and comprehend the contents.

The realizing a cohesion device in some texts; either spoken style or written style will give more accessible guide to understand the message of texts especially for the number of eight grades. The students of eighth grade are commonly requested to comprehend the kind of factual and story genres; such as descriptive text and recount text. This study concerns with the monologue as most of the texts are recount texts. In general, using the term of cohesive- which it functions as a connection part of the sentence to another sentence- will create well-organized texts.

Based on the reason above, this study tried to analyze the components of cohesion from students' textbook of curriculum's 2013 at eighth grade. Besides, the primary data was recount text as it was the one of the genres which must be mastered by students. This study was descriptive method with the following steps to collect the data; first, the data were analyzed by dividing and numbering sentences into clauses, second, putting the number of cohesive devices into tables based on types, third, putting the number of cohesive devices in the form of percentage, the last, making an interpretation based on the result.

\section{Background Literature}

\section{Previous Study}

There are some references as the previous study that is helpful to finish this study. Here, there are two references which are selected for supporting this study;

a. The first reference belongs to the thesis "Grammatical Cohesion Found in Recount Texts of "Pathway to English" X Grade Curriculum 2014 General Program by Erlangga" which is organized by HanitaMasithoh from English Education Department UIN Walisongosemarang 2016. That study prefers to know the quality of the texts books, as the students' primary source and focuses on finding grammatical cohesion of recount text. This study uses qualitative as research design, and it is found that there are three recount texts in Pathway to English. Text 1 and 3 contained three types of grammatical cohesion (reference, ellipsis, conjunction). Text 2 contained complete grammatical cohesion (reference, substitution, ellipsis, conjunction). This textbook categorizes as fair criteria because the percentage of grammatical cohesion is $33 \%$.

b. The second reference comes from the theses too published in 2017 "Analysing Cohesion of Monologue Texts Found in Paper-Based National Examination for Junior High School in The Academic Year of 2016/2017". This study aims to describe and analyze the type of cohesive 
devices and the most of them in every package of paper-based national examination for Junior High School, its subject is monologue texts which are found in the paper-based national examination. This study used qualitative approach. The data were analyzed by some steps. First, the data were analyzed by dividing and numbering sentences into clauses. Second, putting the number of cohesive devices into tables based on types. Third, putting the number of cohesive devices in the form of a percentage. The last, making an interpretation based on the result.

c. Moreover, the last, this study concludes that the most cohesive texts found in the certain package. The most cohesive recount texts are found in package 4, and the most cohesive report texts are found in package 3 . It means that those texts are more appropriate to distribute in each package as the script of national examination for Junior High School in the academic year of 2015/2016.

\section{Literature review}

\section{Text and Context}

1) General Text's Definition

According to Halliday and Hasan (1976:1), the text has important role; what we read will define what we get from it. So that, it must be understood it well. Besides, Halliday and Hasan state that the word text is used in linguistics to refer to any passage, spoken or written, of whatever length, that does form a unified whole. Moreover, Siahaan and Shinoda(2008:1) emphasize that text refers to some meaningful short or long spoken or written text. Furthermore, written text is any meaningful written text; it can be a notice, or a direction, or an advertisement, or a paragraph, or an essay, or an article, or a book, etc.

Moreover, Crystal (in Nunan 1993:6) claims the definition of text is a unit regularly effects to the spoken, written or sign which have a purpose. Besides, Cook (in Nunan 1993:6) gives the illustration of text as a language which is interpreted argumentatively without embedding of context. While Suzanne Eggins' book (2004:23), the term 'text' had been explained as "authentic production of human's social interaction. Accurately it is closest with Halliday and Hasan's explanation (1976:1), they defined the word 'text' as any passage, either spoken or written that expresses the whole or unity of structure.

To realize Halliday and Hasan's perspective related to what exactly text is, it can begin with the obvious example below;

\section{U P X G}

W E L I

\section{A C F M}

T R Z B 


\section{J Q N \\ O K S H}

(Adopted from Suzanne Eggins, An Introduction to Systemic Functional Linguistic. $p: 24)$

Despite example regularly above is called as a language in some culture which is known by a human, but it cannot be read as text. There are evident distinctions both text and language; sounds and letters which do not organize the texts. So far, the text is not structurally combination of a sequence of sounds or letters of English language. Besides, that the phonemes which represented by the letters are not calling or functioning as units of meaning (or text).

Besides, Halliday and Hasan (1989:52) exemplify the concrete characteristic of the text is unity. The unity of any texts; either spoken or written that mainly focus on two primary types that are unity of structure and texture. Here, the texture is the device which distinguishes between text and non-text. The texture is what the clauses of a text hang together to create a unity. Moreover, that texture has interaction between two components; coherence and cohesion. Coherence is the relationship between the social and cultural context. Meanwhile, Cohesion is their way of elements within a text hang together as 'unified whole.

Besides, Halliday and Hasan (1989:11-12) classify the text's functions into four important scopes; text as a semantic unit, text as meaning, text as product and process, and text as a social exchange of meaning. Those four functions are apparently and typically involved within the texts, so those functions never mean unconnected to each sentence or paragraph, but its links to each other.

2) General Context's Definition

As Nunan (1993:7) states that context has an urgent role in some discourses which refer to the situational element. Context is everything around the texts. Moreover, the notion of what is 'with the text' (context) always goes to beyond what is said or written, and functions as a complement of the text which makes the whole meaningful meaning (Halliday and Hasan, 1989:5).

Malinowski states (in Halliday and Hasan 1989:6) that the context is divided into two urgent areas; the context of situation and culture. The term 'context' has a similar word 'con-text' which appears before and after every single sentence in the variety of paragraph. Then, He states that the text is uttered has to be included the meaning of environment or verbal situation as the complete the whole meaningful text.

Furthermore, Malinowski emphasizes it was needed to give more scope than the conceptual environment or situation. It is necessary when the reader interprets some texts or utterances (which strange) to provide accurate information not only seen from what is exactly happening but also the total cultural background.

According to Halliday and Hasan (1989:12), who work with the concept of 
context of situational context, He classifies the term of context into three important features which serve to interpret the social context of a text and the environment where the meanings are being exchanged:

1. Field: what is happening, why it is happening, where or to whom

2. Tenor: who are taking apart or the participants

3. Mode: what is the language taking to do interaction (either formal or non-formal)

According to Halliday and Hasan (1989:25), about three elements of context; field, tenor, and mode, each element have the relevance into the texts. Here as follows;

\begin{tabular}{ll}
\hline $\begin{array}{l}\text { A feature of the (realized by) } \\
\text { context }\end{array}$ & $\begin{array}{l}\text { The functional } \\
\text { component } \\
\text { semantic system }\end{array}$ \\
\hline $\begin{array}{ll}\text { Field of discourse } \\
\text { (what is going on) }\end{array}$ & $\begin{array}{l}\text { Experiential meaning } \\
\text { (transitivity) }\end{array}$ \\
\cline { 1 - 1 } $\begin{array}{l}\text { Tenor } \\
\text { (who are taking part) }\end{array}$ & $\begin{array}{l}\text { Interpersonal meaning } \\
\text { (mood or modality) }\end{array}$ \\
\hline $\begin{array}{l}\text { Mode to } \\
\text { (role assigned to }\end{array}$ & $\begin{array}{l}\text { Textual meaning } \\
\text { (theme-rheme) }\end{array}$ \\
\hline language) & \\
\hline
\end{tabular}

It is important to comprehend what must be known that connection between texts and context through the table above. Furthermore, it is true which is explained definitely that text and context are almost seen as two different notions, but it has the depth relevance meaning.

\section{a. Cohesive}

A well-organized text is realized within cohesive features, according to Nunan (1993:21) cohesion is sequences of sentences and utterances which seem to 'hang together' contain what are called text. While Halliday and Hasan (1989:4) classify, grammatical cohesion includes four items as reference, substitution, ellipsis, and conjunction. Besides, lexical cohesion is divided into reiteration (repetition, synonymy, etc.) and collocation (cooccurrence of lexical items).

Furthermore, Halliday and Hasan (1989:31) mention four grammatical cohesion with their explanation and examples;

\section{1) Reference}

One of four grammatical cohesions which refer to how the writer/speaker introduces participants and then keeps track of them once they are in the text is a reference. 
Participants are the people, places, and things that get talked about in the text. It is potentially cohesive relation because the thing serves as the source of the interpretation of element of the text. It means a reference plays as to emphasize or repeating of the participants in the texts.

Then, they classify the term of reference into anaphoric and cataphoric reference, each of the two definitions is stated below;

"Donald Trump announced several smaller moves, like liquidation of his securities portfolio. $\underline{\mathrm{He}}$ also said he would also donate any profits from foreign government payments at his hotels to the US treasury."

(accessed from www.thejakartapost.com, on 04 of March 2017)

Through the news above, it expresses the word Donald Trump, and $\underline{H e}$ refers to a single individual whose identity is established in the opening sentence. The subsequent items can only be interpreted concerning initial phrase of this first sentence. This type of device is known as an anaphoric reference. The way to identify anaphoric form is the first word of texts is the name of the person then followed with its pronoun.

Then, Nunan (1993:22) exploresexophoric reference that recognized as the part of reference with its interpretation lies outside the context, and it can only be found through an examination of the context. For example:

"It is possible that Trump may alter his plan. In his speech, OGE's Shaub did strike an optimistic note".

(accessed from www.thejakartapost.com, on 05 Of March 2017)

The message of this example above is highly implicit, and none of the items $\underline{i t}$ can be interpreted, except by mean of the context of the situation.

According to Halliday and Hasan (1989:54), there are several kinds of references. They are:

\section{a) Personal Reference}

A reference typically functions as speech situation, personal pronoun is mainly derived into; I, me, you, we, us, him, etc. The category of personal includes into three classes; those are; personal pronoun, possessive pronouns (mine, yours, ours, etc.) and possessive identifiers (my, your, our, etc.).

For example:

King Salman bin Abdul Aziz Al Saud expressed his appreciation for Indonesian people who demonstrated inter-religious unity, hoping all citizen would uphold the value of tolerance in society. (accessed from www.thejakartapost.com, on 05 of March 2017)

In the single paragraph above, the underlined words he refers King Salman's word in 
the preceding sentence. The word his is personal reference.

\section{b) Demonstrative reference}

As stated by Nunan (1993:23)that demonstrative reference deals with the term of determiner and adverbs. Here the example of demonstrative reference;

"Recognizing that his country had to change, Gerbachev could have become a cautious modernizer in the Chinese fashion, promoting economic reform and sponsoring new technology while holding firm against political change. This did not happen."

The word "this" categorized as a demonstrative reference which refers to the sentence of Gerbachev...change.

\section{c) Comparative reference}

Besides, Nunan (1993:24) said that comparative reference is typically expressed within the texts through adjective and adverb, for example below;

Queen Elizabeth II visited battalion members of the Royal Welsh Friday and met the regiment's newest mascot, a goat named Fusilier Llywelyn.

(accessed fromInternational Bussiness Times/IBT, on 02 of March 2017)

In the example above, there is a word which signs comparative reference. It is the word newest.

\section{2) Substitution}

Substitution is a relation between linguistic items; such as words and phrases whereas the reference is a relation between meaning. Substitution involves a wider range of construction; not just nouns and pronouns but verbs and proverbs. Nunan (1993:24) divides the type of substation into three parts; nominal, verbal, and causal. The examples below are substation with followed with its specific explanation;

a) Nominal substitution

"There are some new tennis balls in the bag. These' have lost their bounce."

b) Verbal substitution
A. "Annie says you drink too much."
B. "So $\underline{d o}$ you."

c) Clausal substitution
A. "Is it going to rain?"
B. "I think $\underline{s o} . "$

These are three of instances of substitution which are written underlined and italic. The words "ones, do, and so" are categorized as a substitution.

\section{3) Ellipsis}


Shortly, Omitting repeated words and phrases are called Ellipsis. According to Partridge (2000: 138)that ellipsis occurs when an element which can be recovered by referring to a preceding element in the text is omitted. He classifies into three basic;

\section{a) Noun or noun group of ellipsis}

"My kids play an awful lot of sports; both (my kids) are incredibly energetic."

b) Verbal of ellipsis
A. "Have you been working?"
B. "Yes, I have (been working)"

\section{c) clausal ellipsis}

A. "Paul's staying for dinner, isn't he?"

B. "Is he? he didn't tell me (he was staying for dinner)"

There are three kinds of ellipsis - noun, verbal, and clause- which are stated with their specific mark.

\section{4) Conjunction}

It is different from, observed from its function as cohesion device point of view, three types of cohesion above; reference, ellipsis, and substitution. Conjunction plays important role within the texts due to its jobs for making well-organized texts (Nunan, 1993:26). Moreover, there are classifications of conjunction, as follows;

\section{a) Adversative}

"I am afraid I will be home late tonight. However, I won't have to go in until late tomorrow. I quite like being chatted up when I am sitting in a bar having a drink. $\underline{O n}$ the other hand, I hate it if ..."

The relationship signaled by however and on the other hand is adversative because of the information in the second sentence of each text moderates the information in the first.

\section{b) Additive}

"From a marketing viewpoint, the popular tabloid encourages the reader to read the whole page instead of choosing stories. And, isn't that what any publisher wants?"

Here the word "and" signals the presence of additional information.

\section{c) Temporal}

"Brick tea is a blend that has been compressed into a cake. It is taken mainly by the minority groups in China. First, it is ground to dust, $\underline{\text { Then }}$ it is usually cooked in milk." 
Two temporal conjunction; first and then, exists when the events in a text are related regarding the timing of their occurrence.

\section{d) Causal}

"Chinese tea is becoming increasingly popular in restaurants and even in coffee shops. This is because of the growing belief that it has several health-giving properties."

The word "because of" is similar to the meaning "because" which functions to relate to the next word, phrase or clause.

\section{b. Genre}

The term "genre" is preferred to unique category type, spoken or written. Heyland (2002:15)states:

"Genre is a term for grouping texts together, representing how writers typically use language to respond to recurring situations. Every genre has some features which make it different to other genres: each has a specific purpose, an overall structure, specific linguistic features, and is shared by members of the culture."

Based on Hartono (2005:35), the term genre is used to refer particular text types, not to traditional varieties of literature. It is type or kind of text, defined regarding its social purpose also the level of context dealing with a social purpose.

The increase of a little difficulty of recognizing and differentiating of various genres' kinds is based on the societies' point of view that they go difficult for classifying and identification. Therefore, the concept of genre is raised to assist how readers can recognize (Widyaningrum, 2017:23). According to Prastikawati and Musarokah (2010: 10) genre can be well-known as the part of discourse from three basic rhetorical structures; they are, social function, schematic structure, and language features.

This following chart deals with the taxonomy of genres and is followed by its social function, different schematic/generic structure, and different language features.

\begin{tabular}{clll}
\hline Story Genre & & & \\
\hline Genre & Social & Generic & Language \\
& Function & Structure & Feature \\
\hline 1. Narrative & To amuse, to & Orientation, & Material \\
& entertain, and & Complication, process and \\
& to deal with and resolution & mental or \\
& actual & & relational \\
& experiences & & process \\
\hline 2. Recount & To retell the & Orientation, & Material \\
& event to events, and & process, past \\
& inform & Re- & tense, use \\
& & Orientation & temporal \\
\hline
\end{tabular}




\begin{tabular}{|c|c|c|c|}
\hline & & & sequence \\
\hline 3. Anecdote & \begin{tabular}{lr}
\multicolumn{2}{l}{ To share with } \\
others an \\
account of \\
unusual \\
incidents
\end{tabular} & $\begin{array}{l}\text { Abstract, } \\
\text { Orientation, } \\
\text { Crisis, } \\
\text { Reaction, and } \\
\text { Coda }\end{array}$ & $\begin{array}{l}\text { Use if } \\
\text { exclamation, } \\
\text { Material } \\
\text { process and } \\
\text { mental or } \\
\text { relational } \\
\text { process }\end{array}$ \\
\hline 4. Spoof & $\begin{array}{l}\text { To retell an } \\
\text { event with a } \\
\text { humorous } \\
\text { twist }\end{array}$ & $\begin{array}{l}\text { Orientation, } \\
\text { Event(s), and } \\
\text { twist }\end{array}$ & $\begin{array}{l}\text { Material } \\
\text { process and } \\
\text { past tense }\end{array}$ \\
\hline 5. News Story & $\begin{array}{l}\text { To inform } \\
\text { the readers of } \\
\text { daily } \\
\text { newspaper } \\
\text { about events }\end{array}$ & $\begin{array}{l}\text { Newsworthy } \\
\text { events, } \\
\text { background } \\
\text { events, and } \\
\text { sources }\end{array}$ & $\begin{array}{l}\text { Material } \\
\text { process and } \\
\text { past tense }\end{array}$ \\
\hline 6. Exemplum & $\begin{array}{l}\text { To deal with } \\
\text { incidents that } \\
\text { are in some } \\
\text { respect out of } \\
\text { usual }\end{array}$ & $\begin{array}{l}\text { Abstract, } \\
\text { Orientation, } \\
\text { incidents, } \\
\text { judgment, } \\
\text { and re- } \\
\text { orientation }\end{array}$ & $\begin{array}{l}\text { Material } \\
\text { process, past } \\
\text { tense, use of } \\
\text { exclamation, } \\
\text { use of } \\
\text { temporal and } \\
\text { continuative } \\
\text { conjunction }\end{array}$ \\
\hline
\end{tabular}

Factual Genre

\begin{tabular}{clllr}
\hline Genre & Social & Generic & \multicolumn{2}{l}{ Language } \\
& Function & Structure & Feature & \\
\hline \multirow{3}{*}{ 7. Procedure } & To describe & Goal, & Use & of \\
& how & Materials, & material \\
& something is and Steps & process and \\
& accomplished & & simple present \\
& & & tense \\
\hline
\end{tabular}




\begin{tabular}{|c|c|c|c|}
\hline 8. Explanation & $\begin{array}{l}\text { To explain } \\
\text { the process } \\
\text { involved in } \\
\text { the } \\
\text { information } \\
\text { working if } \\
\text { natural } \\
\text { phenomena }\end{array}$ & $\begin{array}{l}\text { General } \\
\text { statement and } \\
\text { specific } \\
\text { explanation }\end{array}$ & $\begin{array}{l}\text { Use of } \\
\text { material } \\
\text { process and } \\
\text { simple present } \\
\text { tense }\end{array}$ \\
\hline 9. Report & $\begin{array}{l}\text { To describe } \\
\text { the way } \\
\text { things are }\end{array}$ & $\begin{array}{l}\text { General } \\
\text { classification } \\
\text { and } \\
\text { description }\end{array}$ & $\begin{array}{l}\text { Use of simple } \\
\text { present }\end{array}$ \\
\hline 10. Description & $\begin{array}{l}\text { To describe } \\
\text { particular } \\
\text { person, } \\
\text { animal, or } \\
\text { thing }\end{array}$ & $\begin{array}{l}\text { Identification } \\
\text { and } \\
\text { description }\end{array}$ & $\begin{array}{l}\text { Use of simple } \\
\text { present }\end{array}$ \\
\hline 11. Discussion & $\begin{array}{l}\text { To present } \\
\text { (at least) two } \\
\text { points of } \\
\text { view about } \\
\text { an issue }\end{array}$ & $\begin{array}{l}\text { Statement and } \\
\text { preview } \\
\text { (issue) and } \\
\text { point and } \\
\text { elaboration } \\
\text { (argument) }\end{array}$ & $\begin{array}{l}\text { Use of simple } \\
\text { present, use of } \\
\text { material, } \\
\text { mental and } \\
\text { relational } \\
\text { process, and } \\
\text { use of } \\
\text { modality }\end{array}$ \\
\hline 12. News Item & $\begin{array}{l}\text { To inform } \\
\text { readers, } \\
\text { listeners, or } \\
\text { viewers } \\
\text { about events } \\
\text { of the day } \\
\text { which is } \\
\text { important }\end{array}$ & $\begin{array}{l}\text { The } \\
\text { newsworthy } \\
\text { event, } \\
\text { background } \\
\text { events, and } \\
\text { sources }\end{array}$ & $\begin{array}{l}\text { Use of } \\
\text { material } \\
\text { process and } \\
\text { verbal process }\end{array}$ \\
\hline
\end{tabular}

\section{c. Monologue Text}

Two kinds of genre; story genre and factual genre both can be included in dialogue and monologue. The term "monologue" is quite complex due to their numerous parts, as stated by Gerot and Wignell (1994:192) monologue is divided into some categories; they are, Recount, Report, Analytical Exposition, news Item, Anecdote, Narrative, Procedure, Description, Hortatory Exposition, Explanation, Discussion. 
Those parts are functional text while short functional texts are invitation, announcement, and advertisement. Nevertheless, this study only focuses on recount text which is taught in eighth grade.

According to Gerot and Wignell (1994:194), they argue count as a text to retell events to inform or entertaining. The purpose of recount text is to give the audience a description of what occurred and when it occurred. The generic structures of recount text are Orientation(provides the setting and introduces participants), events(tell what happened; it usually used sequences to tell what it happened), and ReOrientation(closure of events).

Recount text has several significant lexicogrammatical features. Those are focusing on specific participants and temporal sequence, using material processes, using of past tense, and the last is using circumstances of time and places.

\section{d. Students' textbook}

\section{1) Definition of Text Book}

A textbook takes a significant role in assisting the teaching-learning process; it is a media which mostly teachers refer to. According to Bull (1990:459), the textbook is a book which apparently or gives a big overview of particular subject, and is utilized in certain schools. Besides, in this study, a textbook is English that typically belongs to English students.

English, fortunately, has a number of its functions for English teachers and their students due to its functions provide numerous benefits. Jack C. Richard (2002:245-255) in HanitaMasithoh (2016:114) mentions seven familiar functions of the textbook, as follows;

1. They provide structure and syllabus for a program. Without textbooks a program may have no central core learners may not receive a syllabus that has been systematically planned and developed.

2. They help standardize instruction. The use of a textbook in a program can ensure that the students in different classes receive similar content and therefore can be tested in the same way.

3. They maintain quality. If a well-developed textbook is used, students are exposed to materials that have been tried and tested, that are based on sound learning principles, and that is paced appropriately.

4. They provide a variety of learning resources. The textbook is often accompanied by workbooks, CDs and cassettes, videos, CD ROMs, and comprehensive teaching guides, providing a rich and varied resource for teachers and learners.

5. They are efficient. They save teachers' time, enabling teachers to devote time to teach rather than materials production. 
6. They provide effective language models and input. Textbooks can provide support for teachers whose first language is not English and who may not be able to generate accurate language input on their own.

7. They can train teachers. If teachers have limited teaching experience, a textbook together with the teacher's manual can serve as a medium of initial teacher training.

\section{2) Profile of Text Book}

"When English Rings a Bell" is a students' textbook based on curriculum 2013 which is published by Culture and Education Ministry (2014 edition). This book is massively provided for students in order to master English -as second language- in the school, this book is published through text-based learning, either spoken or written. A comprehend of texts (genres) are emphasized so that students are aware of how language takes its functions through texts.

\section{Research Method}

\section{Research Design}

Research design became the proper way to get the proposed data through certain methods. Besides, this research used descriptive qualitative approach. According to Nunan (1992:3), qualitative research was a research approach that revealed certain social situations by describing the real correctly, the shape of the words based on techniques of collecting and analyzing relevant that the gain from the natural situation. On the other words, qualitative research was research that carried out with the main aim to the given description about a condition objectively.

\section{Source of Data}

Students' texts book(When English Rings a Bell) for Junior High School at eight grades in the academic year of 2017/2018 was the main or primary data as the study of source data. Arikunto (2006: 129) stated that the data resource was the subject from which the data can be found. In this study, the source of data was the recount text found inWhen English Rings a Bell.

\section{The technique of Data Collection}

This part focused on how the data could be obtained, and in this study was conducted through several steps;

\section{1) Selecting the proper textbook}

This study, writer preferred to use When English Rings a Bell textbook of curriculum's 2013 at eight grade published by Education and Culture Ministry as the appropriate textbook.

2) Deciding monologue text 
There were numerous of genres which had to be taught - as presented above- but in this focused study, the writer only preferred to analyze recount text because that genre was massively learned by students' at eighth grade.

\section{The technique of Data Analysis}

The analysis of data would be done in the following four steps;

1) The data were analyzed by dividing and numbering sentences into clauses.

2) Putting the number of cohesive devices into tables based on types.

3) Putting the number of cohesive devices in the form of a percentage.

4) Making an interpretation based on the result.

\section{Findings And Discussion}

\section{Findings}

In the content of students' textbook "When English Rings a Bell" (page 165166), there were eight texts of recount text which are found. All those texts were analyzed through the cohesive device; such as reference, substitution, ellipsis, and conjunction. The table below was commonly the collection of kinds of cohesive;

Table I

\begin{tabular}{|c|c|c|c|c|c|}
\hline NO & Reference & Substitution & Ellipsis & Conjunction & Total \\
\hline 1 & $\begin{array}{l}6 \text { personal } \\
\text { reference }\end{array}$ & - & - & 2 adversative & 8 times \\
\hline 2 & $\begin{array}{l}15 \text { personal } \\
\text { reference }\end{array}$ & - & - & $\begin{array}{l}3 \text { adversative } \\
\text { and } 1 \text { additive }\end{array}$ & 18 times \\
\hline 3 & $\begin{array}{l}5 \text { personal } \\
\text { reference }\end{array}$ & - & - & 1 adversative & 6 times \\
\hline 4 & $\begin{array}{l}7 \text { personal } \\
\text { reference }\end{array}$ & - & - & 2 additive & 9 times \\
\hline 5 & $\begin{array}{l}7 \quad \text { personal } \\
\text { reference }\end{array}$ & - & - & $\begin{array}{l}3 \text { adversative } \\
\text { and } 1 \text { additive }\end{array}$ & 11 times \\
\hline 6 & $\begin{array}{l}9 \text { personal } \\
\text { reference }\end{array}$ & - & 1 verbal & - & 10 times \\
\hline 7 & $\begin{array}{l}7 \text { personal } \\
\text { reference }\end{array}$ & - & - & $\begin{array}{l}1 \text { additive and } \\
1 \text { adversative }\end{array}$ & 9 times \\
\hline 8 & $\begin{array}{l}6 \text { personal } \\
\text { reference }\end{array}$ & - & - & 2 additive & 8 times \\
\hline
\end{tabular}

\section{Data Analysis}


The result of grammatical cohesion analysis of recount text was figured descriptively below;

\section{Text I}

(1) When I was a baby, (2) when I could not do anything, (3) my parent and my elder brother took care of me. (4) My brother was five years older than me. (4) I didn't sleep with my mom. (5) I slept in a baby cot in my parent bedroom. (6) My brother slept in his room. (7) My mom breastfed me for two years.

This was the first text of recount where it was found many cohesive devices; such as reference and conjunction. The word "I and me" belonged to personal reference while when was conjunction.

\section{Text II}

(1) WhenI cried, (2) they calmed me down. (3) WhenI was afraid of something, (4) they comforted me. (5) My dad often carried me around in the morning sun. (6) WhenI got older, (7) they spoon-fed me. (8) I played with my brother. (9) I was naughty, (10) but he never got angry with me. (11) He was very patient with me.

The example above was second text of recount text where reference occurred many times; I, me, He, and they whereas conjunction only happened twice; when and but. Therefore, this text II is cohesively well.

\section{Text III}

(1) I started my kindergarten (2) when I was five years old. (3)I did my kindergarten for two years, one year in Kindy A and one year in Kindy B. (4) Mykindy was near my home. (5) I walked to my kindy with my Mom or my sister. (6) Sometimes I went with my dad on his motorcycle.

Text II was a less cohesive device where reference occurred once namely $I$, and conjunction was when.

\section{Text IV}

(1) In the classroom, my teacher read us stories. (2) We sang happy songs, (3) we colored pictures, (4) and we played with dough and colorful paper. (5) In the playground, we played sliding, (6) we ran around, (7) and we also played hide and seek.

The word "We and us" belonged to personal reference where we as the subject of the beginning of the sentence, while "us" as the object of the pronoun.

\section{Text V}

(1) I started my primary school (2) when I was seven years old and finished (3) when I was twelve. (4) I also walked to school, (5) because my school was only 200 meters from my brother or with my friend. (6) Sometimes my dad took me to school on his motorcycle. (7) Sometimes I walked to school by myself. 
Every single clause of this text was really cohesive; it could be found in each clause is full of part of the cohesive device; there was a personal reference such as $I$, myself and means when and as conjunction.

\section{Text VI}

(1) I learned many new things in primary school. (2) I learned to write and to read in grade 1 and grade 2. (3) My favorite teacher was Mrs. Ningrum. (4) She was very smart. (5) She taught us traditional dances and songs. (6) She also taught us to plant trees and (to) took care of the garden. (7) One day she took us to the local library to borrow books.

The instance above was produced cohesive device; personal reference "I, she, and us," and ellipsis in clause 6 "She also .... (to) took care of the garden." Ellipsis played its role to hide the same structure of grammar. And, this text of VI the word "to" was hid.

\section{Text VII}

(1) I had many sweet memories in my primary school. (2) My friends and I often teased Pak Min, the janitor. (3) We hid his broom, his duster, his mop, and his bucket. (4) However, he never got angry. My Physical Education (PE) teacher, (5) Mr. Laode, often took us to walk around the hills and along the river near our school. (6) We took a rest under the trees when we were tired.

In this case, the writer found two kinds of cohesive; personal reference and conjunction. In the clause $1,2,3,4,5$, and six was full of personal reference while conjunction could be found in clause 4 and 6 .

\section{Text VIII}

(1) I learned to ride on a bicycle in the schoolyard in the afternoon after school. (2) And then I could ride in the small streets in the neighborhood, with my friends. (3) My friends and I often spent hours chatting in the small green yard near the Kelurahan office. (4) The boys climbed the big trees. (5) We also swam in the river. (6) It was still very clean at that time. (7) It was very dirty now.

Text VIII, the researcher, found personal references like $I$, we, and it, and followed by a conjunction such as and then

Those were eight texts of recount text which was adopted from students' textbook When English Rings a Bell" (page 165-166), where each of text was organized or constructed cohesively it could generally be categorized as well-organized text. Although there was absent of substitution due to difficult so that the textbook hardly wrote substitution of cohesive.

\section{Conclusion}

Based on the finding above was obviously realized with the table of each type 
of cohesive from every single text. There were four scopes of cohesive which were familiar within the genres-not only recount text but also almost monologue textswere involved. Besides, the students' textbook here is only released three kinds of cohesive; those were reference, ellipsis, and conjunction. Then, most of the cohesive device was a reference, personal reference, which mostly realized in every single clause, then followed by the conjunction "additive and adversative"...

Furthermore, there was evidence based on the findings (affirmed with some literature review) why the most of cohesive device was a reference because of easy since the reference was comprised of a personal pronoun or object pronoun, that why students were easily used a reference to construct or compile the texts.

\section{Recommendation}

After presenting and describing some simple conclusions, then here some recommendations were figured for the further good research;

\section{The other writers of textbooks}

a. For the further kinds of sample examples in every unit that discussed genres must be unity or fully of cohesive devices in order to make the texts entirely well-organized

b. For organizing some genres in the textbooks must be completely included all kinds of the cohesive device; reference, ellipsis, substitution, and conjunction. In order that the text was unity and full of texture.

\section{The English teachers}

a. It is important to deliver monologue's unit which discussed genres to master the concept of cohesive.

b. The teachers should introduce functions and sample of cohesive to their students in order that students knew and then utilized its concept in their writing.

c. The teacher should ever, at least twice in writing a chapter, provide numerous exercises of writing, so that students used to be familiar with them. 


\section{References}

Arikunto, Suharsimi (2006). Prosedur Penelitian Suatu Pendekatan Praktik. Jakarta: PT Rineka Cipta.

Bull, Victoria.ed (2008). Oxford Learner's Pocket Dictionary.New York: Oxford University Press.

Cook, G, (1989). Discourse, Oxford: Oxford University Press.

Crystal, D, (1987). The Cambridge Encyclopedia of Language, Cambridge University Press

Fadlilah, Sayyidatul. (2010). Cohesion Analysis of Reading Texts Used in English textbooks for Islamic Studies, Research report, Semarang: Fakultas Ilmu Tarbiyah UIN Walisongo.

Fani, Entika, Prastikawati, and Siti Musarokah. (2010). Writing 3. Handout \& Assignments.

Gerot and Wignell. (1994). Making Sense of Functional Grammar, Australia: Gerd Antipodean Educational Enterprises.

Halliday and Hasan. (1976). Cohesion in English. Singapore: Longman Singapore Publishers.

Halliday and Hasan. (1989). Language, Context, and Text: Aspects of Language in Social-semiotic Perspective, Hongkong: Oxford University Press.

Hartono, Rudi. (2005). Genre-Based Writing. Semarang: English Department of Semarang State University.

Heyland, Ken. (2002). Teaching and Researching Writing. Pearson: Longman.

Malinowski. (1935). (in Halliday and Hasan 1989)The Problem of Meaning in Primitive Languages, Kegan Paul, London.

Masithoh, Hanita. (2016). Grammatical Cohesion Found in Recount Texts of "Pathway to English" X Grade Curriculum 2014 General Program by Erlangga, Thesis, English Education Department UIN Walisongo Semarang. 
Nunan, David. (1993). Introducing Discourse Analysis. England: Penguin English.

Nunan, David. (1992). Research Method in Language Learning. USA: Cambridge University.

Nuraini, Dewi. (2017). Analysing Cohesion of Monologue Texts Found in PaperBased National Examination for Junior High School in The Academic Year of 2016/2017, Thesis, English Education Department UIN Walisongo Semarang.

Richards, Jack. (2002). In HanitaMasithoh (2016)Curriculum Development in Language Teaching. Cambridge: Cambridge University Press.

Siahaan and Shinoda. (2008). Generic Text Structure, Yogyakarta: Graha Ilmu.

Widyaningrum, Leily. (2017). The Application of CIRC (Cooperative Integrated Reading and Composition) on Learning Writing of Descriptive Text, A Study at Mts NU Nurul Huda Kudus in the Academic Year of 2016/2017, Thesis, English Education Department UIN Walisongo Semarang. 